Article

\title{
Adsorptive Removal of Pyridine in Simulation Wastewater Using Coke Powder
}

\author{
Qieyuan Gao ${ }^{1,2}{ }^{1}$, Lei Wang ${ }^{1, *}$, Zhipeng $\mathrm{Li}^{1,2}$, Yaqi Xie ${ }^{3}$, Qiongqiong $\mathrm{He}^{1}$ and \\ Yongtian Wang 1,* \\ 1 National Engineering Research Center of Coal Preparation and Purification, Xuzhou 221116, China \\ 2 School of Chemical Engineering and Technology, China University of Mining and Technology, \\ Xuzhou 221116, China \\ 3 School of Environmental Science and Spatial Informatics, China University of Mining and Technology, \\ Xuzhou 221116, China \\ * Correspondence: lei.wang@cumt.edu.cn (L.W.); wangyt9495@163.com (Y.W.)
}

Received: 17 June 2019; Accepted: 16 July 2019; Published: 18 July 2019

\begin{abstract}
Pyridine is a toxic component in industrial wastewater, which is difficult to remove using conventional methods. In this study, the cost-effective coke powder was used to remove pyridine from a pyridine simulation wastewater. The removal efficiency and adsorption capacity of pyridine reached up to $67.32 \%$ and $0.4488 \mathrm{mg} / \mathrm{g}$, respectively, at a coke powder concentration of $60 \mathrm{mg} / \mathrm{L}$ and an adsorption time of $30 \mathrm{~min}$. The pyridine removal efficiency and adsorption capacity of coke powder reached saturation when the initial concentration was $40 \mathrm{mg} / \mathrm{L}$. The $\mathrm{pH}$ of 2-12 in the solution was found to have little effect on the pyridine adsorption process of coke powder, while the coke powder with lower ash content was of better adsorbability for pyridine. The coke powder was regenerated by heat treatment, and reused for pyridine adsorption. It was found that the pyridine removal efficiency slightly decreased after nine times of reuse, in addition to a small cumulative weight loss rate of coke powder. Adsorption isotherm analysis showed that the adsorption of pyridine by coke powder could be well described by the Freundlich isothermal adsorption model, indicating multi-molecular layers mainly dominated the adsorption of pyridine on the surface of coke powder.
\end{abstract}

Keywords: adsorbent; adsorption thermodynamics; coke powder; pyridine

\section{Introduction}

Pyridine is often used as a chemical raw material in industry. It mainly comes from coal tar and coal gasification [1]. It is reported that, with the increasing demand for pyridine in the synthesis of acetaldehyde and ammonia, the annual production of pyridine in the world exceeds 20,000 tons [1]. Pyridine is a type of heterocyclic compound that is volatile, toxic, and flammable with a pungent and unpleasant odor [2]. Pyridine and its derivatives have been widely used in agriculture as agricultural pesticides and herbicides, and enter the environment through industrial activities related to pharmaceuticals, textile manufacturing, and chemical synthesis. The concentration of pyridine in wastewater discharged from factories producing pyridine and its derivatives is generally within the range of $20-300 \mathrm{mg} / \mathrm{L}$. During emergency spills, the concentration can be as high as $600-1000 \mathrm{mg} / \mathrm{L}$. At a pyridine concentration of $0.82 \mathrm{mg} / \mathrm{L}$ in wastewaters, unpleasant pyridine odor is easily detectable. The hazard of exposure to pyridine includes the impacts on livers, kidneys, immune systems, and reproductive functions, as well as potential carcinogenicity [3]. Due to the benzene ring in the structure, pyridine is generally stable and difficult to remove from aqueous solution using traditional organic water treatment methods including the biochemical method, advanced oxidation method, and physicochemical method. 
Biological treatment has been tried to remove pyridine in pyridine-containing wastewater. In recent years, various pyridine-specific degrading bacteria including Pseudomonas, Bacillus, Arthrobacte, Pseudonomica sp., Paracoccus, Lysinibacillus, Red Rhodococccus and Algenes have been isolated and screened in wastewater, sludge, soil, rock, and other sources [4-11]. However, the method is currently in development phase in laboratory environment, and it generally suffers from the long treatment cycle and large environmental impact on bacteria.

An attempt was also made to remove pyridine in wastewater using the advanced oxidation method. However, the method can only be used as a pretreatment process for pyridine removal. Padoley et al. [12] investigated the treatment of wastewater containing pyridine by Fenton oxidation. A maximum chemical oxygen demand (COD) removal of $66 \%$ from pyridine wastewater, along with $62.4 \%$ pyridine removal was obtained under optimum conditions $\left(3.0 \mathrm{~g} / \mathrm{L}\right.$ of $\mathrm{Fe}^{2+}, 900 \mathrm{ppm} \mathrm{of} \mathrm{H}_{2} \mathrm{O}_{2}$ dose, $\mathrm{pH}$ of 3 , contact time of $180 \mathrm{~min}$ ). This Fenton-pretreated pyridine wastewater was further treated via biodegradation using the isolated Pseudomonas pseudoalcaligenes-KPN in batch culture experiments, wherein the residual pyridine removal efficiency was observed to be $84 \%$. In another study by $\mathrm{Xu}$ et al. [13], pyridine organic wastewater was treated by vaporative desalination/micro-electrolysis/Fenton oxidation, and the pyridine removal rate was observed above $95 \%$. In the Fenton reagent oxidation stage, however, the removal rate of COD was only $30.41 \%$ under the optimum operating conditions ( $\mathrm{pH}$ of $4,30 \% 3.5 \mathrm{ml} / \mathrm{L}$ of $30 \% \mathrm{H}_{2} \mathrm{O}_{2}$ dose, contact time of $150 \mathrm{~min}$, and molar ratio of $\mathrm{Fe}^{2+}$ to $\mathrm{H}_{2} \mathrm{O}_{2}$ of 1:20). Apparently, the advanced oxidation method alone is unlikely to remove pyridine efficiently, and for a better pyridine removal rate, the combination of other processes is required.

Apart from the biochemical method and advanced oxidation method, physicochemical method has been widely employed to treat pyridine-containing wastewater [14]. The physicochemical method, which is a single physical or chemical method, or a combination of the physical and chemical methods, is a versatile technique for wastewater treatment. It mainly includes the coagulation method, membrane separation method, adsorption method, distillation method, and incineration method. The coagulation method is simple, but literature suggests that a high removal rate of pollutants in wastewater containing pyridine is unachievable [15]. Besides, a large amount of flocculants added in the system would also cause severe environmental pollution. The membrane separation method has the advantages of energy saving, pollution-free, and simple operation, but it requires the synthesis of expensive membrane materials. In addition, it has been found that, the membrane separation method can only be applied to treat wastewater with a low concentration of organic pollutants, indicating that the method is not appropriate for pyridine-containing wastewater treatment when the pyridine concentration is relatively high. The distillation method has been evidenced to separate pyridine from wastewater well in a number of studies [16]. For example, Kuang et al. [17] used continuous distillation process to treat pyrethroid pesticide wastewater with a high concentration of pyridine, and up to $98 \%$ of the pyridine could be removed. It is worth noting that, however, distillation technology utilizes the difference of the boiling point of a substance, and thus it can only be applied to the separation of pollutants that differ greatly in their boiling points.

In comparison with the abovementioned methods, the adsorption method has proven to be the most practical for the removal of pyridine in wastewater [18]. It uses the porous surface of adsorbents to adsorb solutes and colloids so that wastewater can be purified [19]. The most common adsorbents include activated carbon, sulfonated coal, adsorbent resin, slag, and diatomite [20]. Lataye et al. [21] studied the adsorption of pyridine in the aqueous solution with bagasse fly ash (BFA) as an adsorbent. In solutions with a low pyridine concentration $\left(<50 \mathrm{mg} / \mathrm{dm}^{3}\right)$ and a high pyridine concentration $\left(<600 \mathrm{mg} / \mathrm{dm}^{3}\right)$, the maximum pyridine removal rates determined by $25 \mathrm{~kg} \mathrm{M}^{-3}$ BFA at a normal temperature were found to be $99 \%$ and $95 \%$, respectively. The removal of pyridine adsorbed by BFA was efficient using this simple process, though the limited source of BFA restricts this adsorbent from being used to treat wastewater on a large scale.

Gosu et al. [22] synthesized nano-zerovalent iron (NZVI) particles supported on granular activated carbon (GAC) to treat pyridine-containing wastewater, and the maximum removal efficiency of 
pyridine was found to be $86 \%$. The removal rate of pyridine was high by this adsorbent despite of the fact that preparation of the adsorbent is complicated which makes the whole experimental process troublesome, time wasting, and costly.

Treating pyridine-containing wastewater was also attempted using coking coal as an adsorbent by Ning et al. [23]. In their study, the removal rate of pyridine reached up to $65 \%$ without adjusting acidity and alkalinity at a treatment time of $60 \mathrm{~min}$ and a coking coal concentration of $30 \mathrm{~g} / \mathrm{L}$. The adsorption reached saturation when pyridine concentration reached $30 \mathrm{mg} / \mathrm{L}$, and a further increase in the pyridine concentration would not improve the removal effect. The adsorption was also strongly $\mathrm{pH}$ dependent, and the pyridine removal rate deteriorated as the solution $\mathrm{pH}$ increased. Besides, as coking coal is thermally unstable, its reusability is generally low especially when processed by heat treatment after adsorption [24].

It should be noted that the requirement for sustainable industrial wastewater treatment technology should include the following key elements: A sorbent with good sorption properties along with a low price and the sorbent after adsorption could enter a regeneration process [24]. Coke powders are expected to be promising to remove pyridine from wastewater. Coke powders have strong adsorption capacity and large specific surface area. Plenty of coke powders are produced in the process of coke utilization each year from industries (e.g., the metallurgical, chemical, calcium carbide, and others), of which the price is only one fifth of that of metallurgical coking coals approximately. Besides, after adsorption, coke powders can go back into the coking system, which is not expected to cause extra trouble.

The adsorption behavior of coke powder has been studied in a number of studies. Luo et al. [25] investigated the characteristics and mechanism on the adsorption of methylene blue by coke powder at the laboratory scale. The adsorption capacity of coke powder to methylene blue was $3 \mathrm{mg} / \mathrm{g}$, and the removal rate of methylene blue was 53.3\% under the optimum conditions (oscillation time of $80 \mathrm{~min}$, $\mathrm{pH}>10,16 \mathrm{~g} / \mathrm{L}$ of coke powder, initial concentration of methylene blue in wastewater $<20 \mathrm{mg} / \mathrm{L}$ ). The adsorption behavior was found to obey the Langmuir adsorption isotherm equation, indicating that the adsorption was a spontaneous endothermic process, which was dominated by physical attachment, i.e., intra-particle diffusion. Dong et al. [26] carried out laboratory adsorption tests to study the adsorption of fluoride ion by waste coke powders. In their study, the effect of fluorine-containing wastewater $\mathrm{pH}$, adsorbent concentration, initial fluoride concentration and adsorption time on fluorine adsorption were investigated. The results showed that coke powder could effectively adsorb fluoride with the adsorption capacity of $20 \mathrm{mg} / \mathrm{g}$ and a removal rate of fluoride of $66.7 \%$ at the optimum condition (temperature of $289 \mathrm{~K}$, oscillator speed of $150 \mathrm{r} / \mathrm{min}$, $\mathrm{pH}$ of 5, treatment time of $120 \mathrm{~min}$, the coke powder concentration of $10 \mathrm{~g} / \mathrm{L}$, and the fluoride concentration of $60 \mathrm{mg} / \mathrm{L}$ ). The equilibrium solution concentration reached the national drinking water standard.

However, little work or no work has been done to treat pyridine-containing water using coke powder. This paper studies the treatment of pyridine-containing wastewater using coke powder. It was investigated the effect of coke powder concentration, contact time, initial pyridine concentration, ash content in coke powder, solution $\mathrm{pH}$, and the reuse of coke powder after adsorption on the pyridine removal. The mechanism of the adsorption of pyridine by coke powder was also explored using Langmuir, Freundlich, and Temkin isothermal adsorption models.

\section{Materials and Methods}

\subsection{Materials}

The pyridine, sulphuric acid, and sodium hydroxide were supplied by Sinopharm Chemical Reagent Co., Ltd (Shanghai, China). All chemicals used in this study were of analytical reagent (AR) standard. Coke powder, used as an adsorbent, was obtained from the coking plant of Shandong Rongxin Coal Chemical Industry Group Co., Ltd (Jining, China). Coke powder (below $0.5 \mathrm{~mm}$ ) was crushed, ground, sieved through a $74 \mu \mathrm{m}$ sifter, and dried at $100{ }^{\circ} \mathrm{C}$ in an oven for $2 \mathrm{~h}$ before use. After 
drying, the adsorbent was stored in sealed glass containers. In this study, two types of coke powder were used, with an ash content of $27.37 \%$ and $12.78 \%$, respectively. Note that, the coke powder with an ash content of $27.37 \%$ was used to identify the effect of different conditions on the pyridine adsorption, unless stated elsewhere.

The filtrate was analyzed using a UV-vis spectrophotometer (UV-4802S, Shimadzu, Kyoto, Japan) by which the residual concentration of pyridine in the solution can be determined. The chemical composition of the coke powder was determined by X-ray fluorescence (XRF, Model S8 TIGER, Bruker, Karlsruhe, Germany), X-Ray diffraction (XRD, Model D8 Advance, Bruker, Karlsruhe, Germany), and fourier-transform infrared spectroscopy (FT-IR, VERTEX 80v, Bruker, Karlsruhe, Germany). The surface properties of coke powder were examined by scanning electron microscope (SEM, Tecnai G2 F20, FEI, Hillsboro, NH, USA).

\subsection{Methods}

\subsubsection{Batch Adsorption Tests}

For each adsorption test, a certain amount of pyridine stock solution of $1.00 \mathrm{~g} / \mathrm{L}$ was pipetted to a $100 \mathrm{~mL}$ conical flask. Deionized water was added to the flask to a pyridine solution with a volume of $V$ (L). The pyridine concentration in this diluted solution was the initial concentration $C_{0}(\mathrm{mg} / \mathrm{L}) . m(\mathrm{~g})$ Coke powder was then added to the solution for pyridine adsorption. The conical flask was sealed with a plastic wrap and shaken in a thermostatic water bath shaker with the temperature controlled at $T(\mathrm{~K})$ for $t(\mathrm{~min})$. After shaking, the solution was filtered, and the residual pyridine concentration in the filtrate was determined using the spectrophotometer. The maximum absorbance wavelength of pyridine was found to be $254 \mathrm{~nm}$.

Equation (1) gives the calculation of the adsorption capacity of the coke powder, $Q_{t}$, at the time $t$ :

$$
Q_{t}=\frac{\left(C_{0}-C_{t}\right) V}{m}
$$

where $Q_{t}$ is the adsorption capacity, i.e., the amount of coke powder at the time $t(\mathrm{mg} / \mathrm{g}), C_{t}$ is the concentration of pyridine in the solution at the time $t(\mathrm{mg} / \mathrm{L}), V$ is the volume of pyridine solution $(\mathrm{L})$, and $m$ is the dosage of coke powder (g).

Equation (2) shows the calculation of the removal efficiency of pyridine in the solution after time $t$ :

$$
R_{t}=\frac{\left(C_{0}-C_{t}\right)}{C_{t}}
$$

where $R_{t}$ is the removal efficiency of pyridine in the solution after the time $t(\%)$.

Then the removal of pyridine from solution was investigated with respect to coke powder concentration, contact time, initial pyridine concentration, ash content in coke powder, solution $\mathrm{pH}$, and the reuse of coke powder after adsorption at the required conditions.

To study the effect of coke powder concentration on adsorption, different amounts of coke powder were added to a $50 \mathrm{~mL}$ of solution with a pyridine concentration of $40 \mathrm{mg} / \mathrm{L}$ in the bath shaker oscillated at $150 \mathrm{r} / \mathrm{min}$ for $30 \mathrm{~min}$ at $298 \mathrm{~K}$. The tested concentrations were 5, 10, 15, 20, 40, 60, 80, and $100 \mathrm{~g} / \mathrm{L}$, respectively. The tested concentrations were $5,10,15,20,40,60,80$, and $100 \mathrm{~g} / \mathrm{L}$, respectively. Note that, in our previous work, a higher oscillation speed has been tried to reduce the mass transfer resistance. However, it was found that the removal efficiency of pyridine did not increase apparently, or even decreased due to desorption of pyridine occurred in the process of adsorption as oscillation speed increased. Therefore, an oscillation speed of $150 \mathrm{r} / \mathrm{min}$ was used in this study. The identified optimum coke concentration (in this case, $60 \mathrm{~g} / \mathrm{L}$ ) was selected as the coke concentration condition for subsequent adsorption batch tests. To identify the effect of the contact time on the removal of pyridine, a $50 \mathrm{~mL}$ solution with $40 \mathrm{mg} / \mathrm{L}$ of pyridine and $60 \mathrm{~g} / \mathrm{L}$ of coke powder was oscillated in a constant temperature water bath shaker at an oscillation speed of $150 \mathrm{r} / \mathrm{min}$ at $298 \mathrm{~K}$ for different 
time. The contact time examined in this study was 5, 10, 20, 30, 40, 60, and $90 \mathrm{~min}$, respectively. This identified optimum contact time ( $30 \mathrm{~min}$ ) would be used for subsequent adsorption batch tests. To identify the effect of the initial pyridine concentration on the removal of pyridine in solution, different initial pyridine concentrations were used and they were 5, 10, 25, 40, and $80 \mathrm{mg} / \mathrm{L}$, respectively. Note that, when the initial pyridine concentrations were changed, the amount of coke powder added to the solution also changed, and the ratio between the initial pyridine concentration and coke powder concentration was kept at $(1 \mathrm{~g} / \mathrm{L}$ of coke powder $) /(0.67 \mathrm{mg} / \mathrm{L}$ of pyridine $)$. This ratio was selected so that the unsaturated adsorption of pyridine by coke powder was achieved, and at the same time, the possibility to cope with a high concentration of pyridine by coke powder was also explored. The prepared sample was oscillated at $150 \mathrm{r} / \mathrm{min}$ for $30 \mathrm{~min}$ at $298 \mathrm{~K}$ in the bath shaker. The optimum initial pyridine concentration (in this case, $40 \mathrm{mg} / \mathrm{L}$ ) was selected as the initial pyridine concentration condition for subsequent adsorption batch tests.

To explore the effect of ash content in coke powder on the removal of pyridine in solution, coke powder $(-74 \mu \mathrm{m})$ with different ash contents was used in the batch adsorption test. The high and the low ash content were $23.73 \%$ and $12.78 \%$, respectively. The pyridine concentration, coke powder concentration, oscillation speed, contact time, and temperature were $40 \mathrm{mg} / \mathrm{L}, 60 \mathrm{~g} / \mathrm{L}, 150 \mathrm{r} / \mathrm{min}, 30 \mathrm{~min}$, and $298 \mathrm{~K}$, respectively.

The effect of $\mathrm{pH}$ on the removal of pyridine in solution was investigated by performing batch adsorption tests at the solution $\mathrm{pH}$ ranging from 2 to 12 . A $50 \mathrm{~mL}$ solution with $40 \mathrm{mg} / \mathrm{L}$ of pyridine and $60 \mathrm{~g} / \mathrm{L}$ of coke powder after $\mathrm{pH}$ regulation was oscillated in a constant temperature water bath shaker at an oscillation speed of $150 \mathrm{r} / \mathrm{min}$ for $30 \mathrm{~min}$ at $298 \mathrm{~K}$. The $\mathrm{pH}$ of the solution was adjusted using sulfuric acid and sodium hydroxide.

Regeneration of adsorbents is an important indicator for effective adsorbents, and in this study thermal desorption was used to regenerate the coke powder in view of its good mechanical strength and heat resistance. The regeneration of the coke powder was carried out in a resistance furnace (CTM-300, Tairui Instruments and Equipment Co., Ltd., Xuzhou, China) with a heating temperature up to $573 \mathrm{~K}$ for $120 \mathrm{~min}$. Then the regenerated coke powder with a concentration of $60 \mathrm{~g} / \mathrm{L}$ was re-used to treat $50 \mathrm{~mL}$ solution with $40 \mathrm{mg} / \mathrm{L}$ of pyridine in the water bath shaker at an oscillation speed of $150 \mathrm{r} / \mathrm{min}$ for $30 \mathrm{~min}$ at $298 \mathrm{~K}$.

Table 1 summarizes the parameters and conditions involved in the abovementioned tests. Each of these tests was repeated three times under the same test conditions, and error bars (i.e., standard deviation) were estimated based on these replicates.

Table 1. The parameters and conditions of batch adsorption tests in this study.

\begin{tabular}{|c|c|c|c|c|c|c|c|}
\hline $\begin{array}{l}\text { Conditions } \\
\text { Parameters }\end{array}$ & $\begin{array}{c}\text { Pyridine } \\
\text { Concentration }(\mathrm{mg} / \mathrm{L})\end{array}$ & $\begin{array}{c}\text { Coke Powder } \\
\text { Concentration }(\mathrm{g} / \mathrm{L})\end{array}$ & $\begin{array}{c}\text { Oscillation } \\
\text { Speed }(\mathrm{r} / \mathrm{min})\end{array}$ & $\begin{array}{l}\text { Contact Time } \\
\text { (min) }\end{array}$ & $\begin{array}{c}\text { Ash Content } \\
(\%)\end{array}$ & $\begin{array}{l}\text { Temperature } \\
\text { (K) }\end{array}$ & $\mathrm{pH}$ \\
\hline $\begin{array}{l}\text { Coke powder } \\
\text { concentration }\end{array}$ & 40 & $5-100$ & 150 & 30 & 27.37 & 298 & - \\
\hline Contact time & 40 & 60 & 150 & $5-90$ & 27.37 & 298 & - \\
\hline $\begin{array}{l}\text { Initial pyridine } \\
\text { concentration }\end{array}$ & $5-80$ & 60 & 150 & 30 & 27.37 & 298 & - \\
\hline Ash content & 40 & 60 & 150 & 30 & $27.37,12.78$ & 298 & - \\
\hline $\mathrm{pH}$ & 40 & 60 & 150 & 30 & 27.37 & 298 & $2-12$ \\
\hline $\begin{array}{l}\text { Regeneration of } \\
\text { adsorbents }\end{array}$ & 40 & 60 & 150 & 30 & 27.37 & 298 & - \\
\hline
\end{tabular}

\subsubsection{Adsorption Isotherm Analysis}

The adsorption tests were conducted at various time intervals to determine the time when adsorption reached equilibrium and the maximum removal of pyridine. The equilibrium adsorption amount, $Q_{e}$, was calculated using Equation (3):

$$
Q_{e}=\frac{\left(C_{0}-C_{e}\right) V}{m}
$$


where $Q_{e}$ is the equilibrium adsorption amount $(\mathrm{mg} / \mathrm{g}), C_{e}$ is the residual concentration of pyridine in solution at adsorption equilibrium $(\mathrm{mg} / \mathrm{L})$.

In this study, adsorption tests were conducted with the initial pyridine concentration set at 5,10 , 20,30 , and $50 \mathrm{mg} / \mathrm{L}$, respectively. Two grams of coke powder was added to a $50 \mathrm{~mL}$ solution with the required initial pyridine concentration. The temperature was kept at $298 \mathrm{~K}$. Langmuir, Freundlich, and Temkin isotherms were used to fit the isotherm data. Langmuir isothermal adsorption equation and linear expression are given [26]:

$$
\begin{gathered}
Q_{e}=\frac{K_{L} q_{m} C_{e}}{1+K_{L} C_{e}} \\
\frac{C_{e}}{Q_{e}}=\frac{C_{e}}{q_{m}}+\frac{1}{K_{L} q_{m}},
\end{gathered}
$$

where $K_{L}$ is the adsorption constants in Langmuir $(\mathrm{L} / \mathrm{mg})$ and $q_{m}$ is the monolayer adsorption capacity $(\mathrm{mg} / \mathrm{g})$.

Freundlich isothermal adsorption equation and linear expression are given [27]:

$$
\begin{gathered}
Q_{e}=K_{F} C_{e}^{\frac{1}{n}} \\
\ln Q_{e}=\ln K_{F}+\frac{1}{n} \ln C_{e}
\end{gathered}
$$

where $K_{F}$ is the adsorption constants in Freundlich $(\mathrm{L} / \mathrm{mg})$ and $1 / n$ is the parameter for evaluating the superiority of adsorption.

Temkin isothermal adsorption linear expression is given [28,29]:

$$
Q_{e}=\left(\frac{R_{T}}{b_{T}}\right) \ln C_{e}+\frac{\left(R T \ln K_{T}\right)}{b_{T}}
$$

where $T$ is absolute temperature $(\mathrm{K}), \mathrm{R}$ is the ideal gas constant $(8.314 \mathrm{~J} / \mathrm{mol}), K_{T}$ is the adsorption constant $(\mathrm{L} / \mathrm{mg})$ in Temkin, and $B_{T}$ is a parameter related to adsorption heat $(\mathrm{KJ} / \mathrm{mol})$.

\section{Results and Discussion}

\subsection{Coke Powder Properties}

The properties of the coke powder used for this study were analyzed using the XRF and XRD, and the results are shown in Table 2 and Figure 1.

Table 2. The results from the quantitative analysis of coke powder content by XRF

\begin{tabular}{cccccccc}
\hline Content (\%) & $\mathbf{S i O}_{\mathbf{2}}$ & $\mathbf{C a O}$ & $\mathbf{A l}_{2} \mathbf{O}_{\mathbf{3}}$ & $\mathbf{F e}_{\mathbf{2}} \mathbf{O}_{3}$ & $\mathbf{M g O}$ & $\mathbf{K}_{\mathbf{2}} \mathbf{O}$ & $\mathbf{N a}_{\mathbf{2}} \mathbf{O}$ \\
\hline Coke powder (Ash 27.37\%) & 6.15 & 4.58 & 5.36 & 2.62 & 0.52 & 0.14 & 0.11 \\
Coke powder (Ash 12.78\%) & 2.67 & 2.13 & 2.24 & 0.98 & 0.31 & 0.10 & 0.09 \\
\hline
\end{tabular}




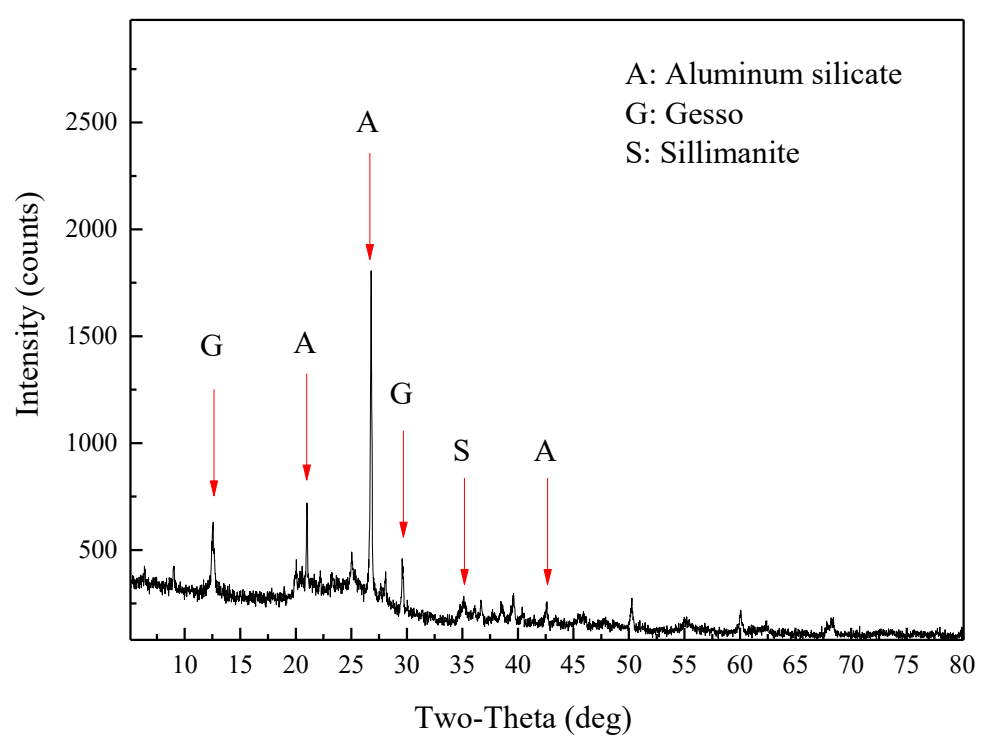

Figure 1. X-ray diffraction patterns of the coke powder used in this study.

As can be seen, the content of inorganic components in both the coke powder was relatively low. Aluminum silicate, gesso, and sillimanite were three main inorganic substances found in the coke powder. The lower content of clay minerals is known to be beneficial for the subsequent solid-liquid separation to calculate the removal efficiency and adsorption amount [30].

Figure 2 shows the surficial morphologies of the coke powder with different ash contents. The surface of both the coke powder was found rough and uneven. This porous structure on the coke powder surface would potentially increase the possibilities of pollutants adsorption [31].

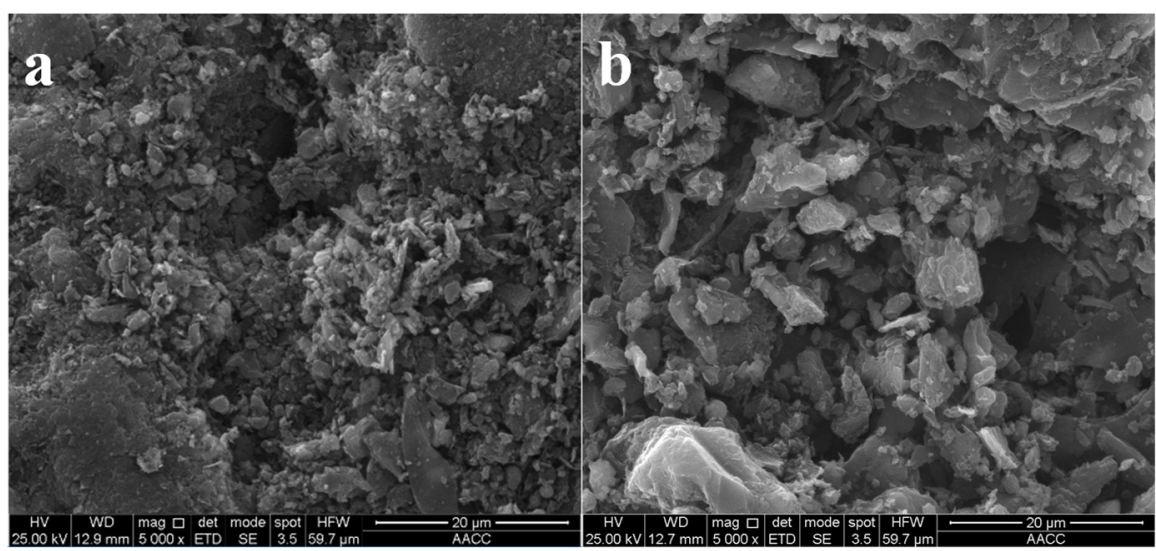

Figure 2. Surface morphologies of the coke powder with an ash content of (a) $27.37 \%$ and (b) $12.78 \%$.

Figure 3 shows the $\mathrm{N}_{2}$ adsorption/desorption isotherm of coke powder with different ash contents. According to the International Federation of Pure and Applied Chemistry, the isotherm of coke powder should belong to type IV. This indicates that the adsorption of coke powder on $\mathrm{N}_{2}$ is mainly due to mesopores. Table 3 shows the results of the coke powder properties related to the pore examined using the automatic nitrogen adsorption instrument. No significant difference was found between these two types of the coke powder. For coke powder with $27.37 \%$ ash content, the specific surface area, average pore size, total pore volume, and mesopore volume of the pulverized coke powder were $51.54 \mathrm{~m}^{2} / \mathrm{g}, 3.23 \mathrm{~nm}, 0.019 \mathrm{~cm}^{3} / \mathrm{g}$, and $0.019 \mathrm{~cm}^{3} / \mathrm{g}$, respectively. For coke powder with $12.78 \%$ ash content, the specific surface area, average pore size, total pore volume, and mesopore volume of the pulverized coke powder were $63.46 \mathrm{~m}^{2} / \mathrm{g}, 3.55 \mathrm{~nm}, 0.020 \mathrm{~cm}^{3} / \mathrm{g}$, and $0.020 \mathrm{~cm}^{3} / \mathrm{g}$, respectively. Although a relatively small specific surface area and total pore volume were observed in the coke 
powder, a large amount of mesopores present in the coke powder, as shown in Figure 4, is expected to adsorb large molecule pollutants from the solution [31].

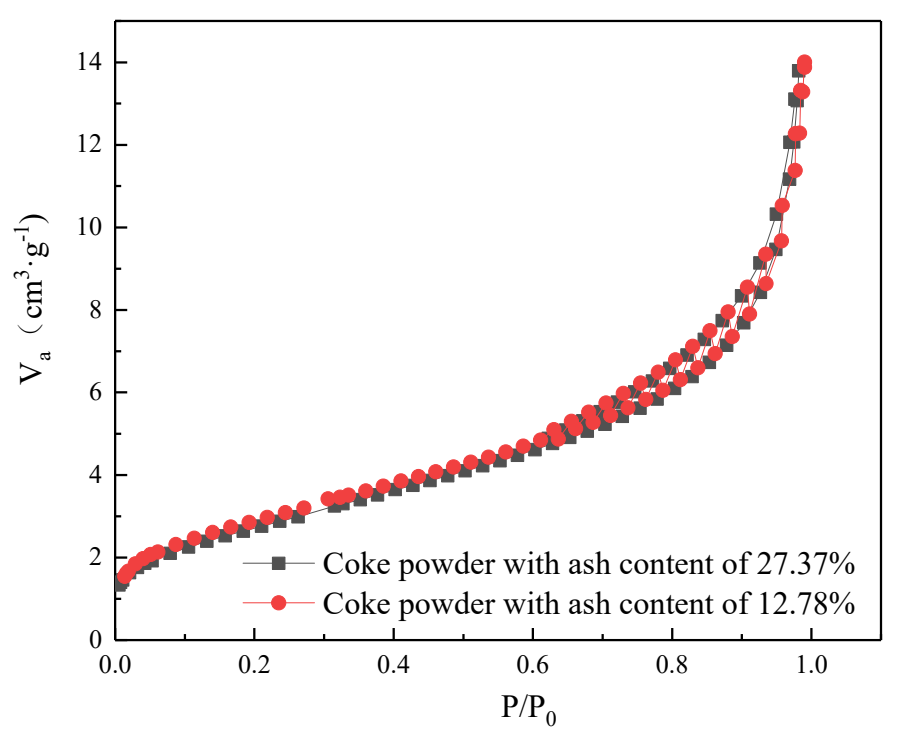

Figure 3. $\mathrm{N}_{2}$ adsorption/desorption isotherm of coke powder.

Table 3. Brunauer-Emmett-Teller (BET) analysis of coke powder.

\begin{tabular}{|c|c|c|c|c|}
\hline & $\begin{array}{l}\text { Specific Surface } \\
\text { Area }\left(\mathrm{m}^{2} / \mathrm{g}\right)\end{array}$ & $\begin{array}{l}\text { Average Pore Size } \\
(\mathrm{nm})\end{array}$ & $\begin{array}{c}\text { Mesoporous } \\
\text { Volume }\left(\mathrm{cm}^{3} / \mathrm{g}\right)\end{array}$ & $\begin{array}{l}\text { Total Pore Volume } \\
\left(\mathrm{cm}^{3} / \mathrm{g}\right)\end{array}$ \\
\hline $\begin{array}{l}\text { Coke powder } \\
\text { (Ash } 27.37 \%)\end{array}$ & 51.54 & 3.23 & 0.019 & 0.019 \\
\hline $\begin{array}{l}\text { Coke powder } \\
\text { (Ash } 12.78 \%)\end{array}$ & 63.46 & 3.55 & 0.020 & 0.020 \\
\hline
\end{tabular}

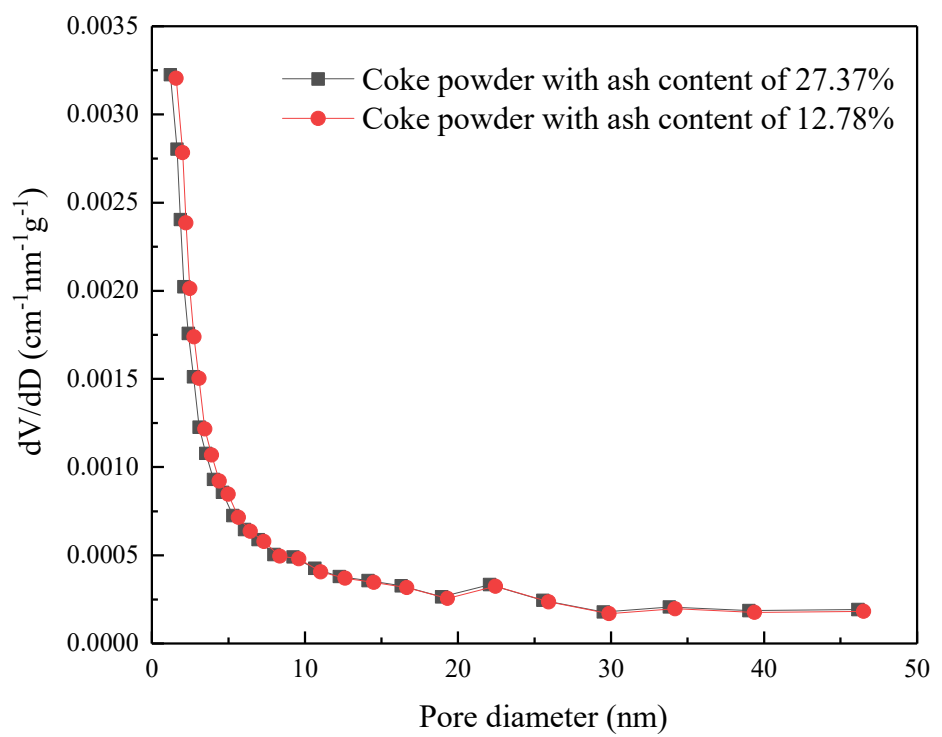

Figure 4. Pore size distribution of the coke powder used in this study examined using the automatic nitrogen adsorption instrument.

\subsection{Effect of Coke Powder Concentration}

Coke powder with different concentrations was used to adsorb pyridine $(40 \mathrm{mg} / \mathrm{L})$ in a $50 \mathrm{~mL}$ solution at an oscillation speed of $150 \mathrm{r} / \mathrm{min}$ for $30 \mathrm{~min}$ at $298 \mathrm{~K}$. The concentrations were $5,10,15,20$, $40,60,80$, and $100 \mathrm{~g} / \mathrm{L}$, respectively. Figure 5 shows the effect of coke powder concentration on the 
efficiency of pyridine removal and adsorption capacity of pyridine by the coke powder. The adsorption capacity decreased with increasing coke powder concentration. The efficiency of pyridine removal increased as the coke powder concentration increased. When the concentration of coke powder reached $60 \mathrm{~g} / \mathrm{L}$, the removal efficiency of pyridine flattened out.

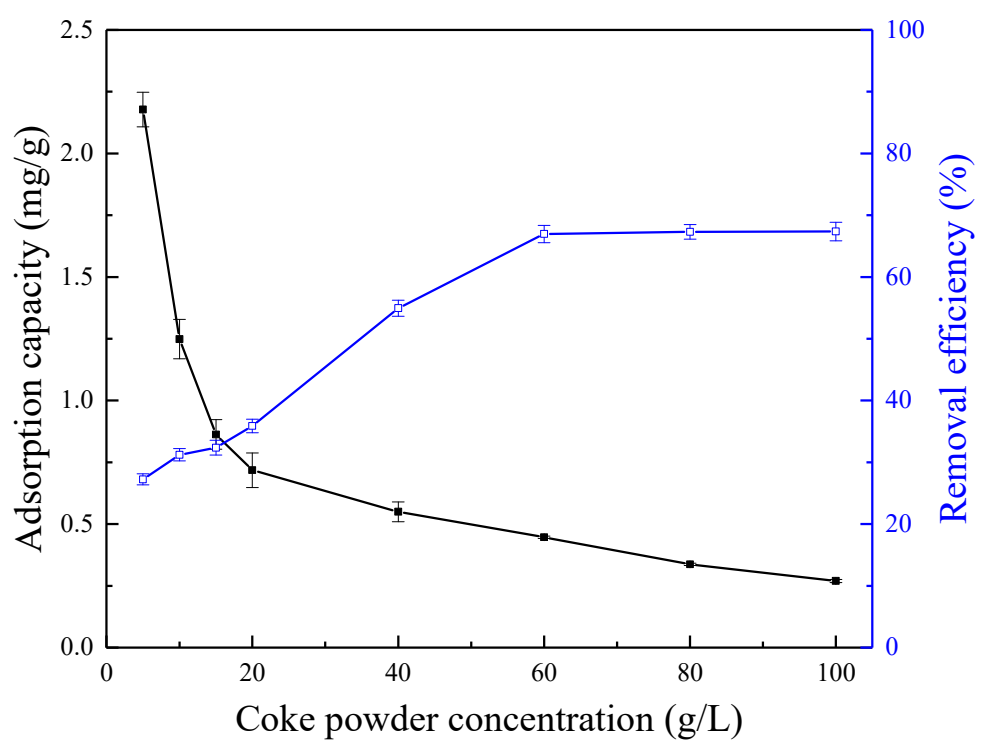

Figure 5. The effect of coke powder concentration on pyridine removal efficiency and adsorption capacity of pyridine.

In general, an increase in the amount of coke powder added to the solution will result in an increase in the total surface area of the coke powder, leading to more pyridine adsorbed by the coke powder and thus an improvement in the pyridine removal. However, the increase in the coke powder concentration will decrease the frequency of the effective collision between pyridine molecules and adsorption sites on unit coke powder surface, resulting in a decrease in the unit adsorption capacity.

It is worth noting that, as the pyridine removal rate no longer increased with increasing coke powder concentration after $60 \mathrm{~g} / \mathrm{L}$ as shown in Figure 5, $60 \mathrm{~g} / \mathrm{L}$ was taken as the optimum concentration in this study.

\subsection{Effect of Contact Time}

A $50 \mathrm{~mL}$ solution with pyridine $(40 \mathrm{mg} / \mathrm{L})$ and coke powder $(60 \mathrm{~g} / \mathrm{L})$ was oscillated at $150 \mathrm{r} / \mathrm{min}$ at $298 \mathrm{~K}$ for 5, 10, 20, 30, 40, 60, and 90 min, respectively. Figure 6 shows the results of the removal of pyridine in the solution after various contact times. With the increase in the contact time, both the pyridine removal efficiency and adsorption capacity increased first and then remained almost the same. There was a sharp increase in the pyridine removal efficiency and adsorption capacity at the beginning of the adsorption. When the contact time reached $30 \mathrm{~min}$, the pyridine removal efficiency and adsorption capacity appeared to reach the maximum, and were found to be $67.32 \%$ and $0.44 \mathrm{mg} / \mathrm{g}$, respectively. After $30 \mathrm{~min}$, both of them barely changed despite of the contact time. At the beginning of adsorption, the coke powder surface was known to have more adsorption active sites, which enables the coke powder to adsorb the pyridine molecules in the solution at a faster rate. After a certain adsorption time, which in these tests was found to be the $30 \mathrm{~min}$, the adsorption sites on the surface of the adsorbent tend to be saturated, and the adsorption rate and desorption rate of the pyridine reach a dynamic equilibrium. In other words, no further adsorption will be achieved after this time. In this study, the optimum adsorption time determined by the tests was $30 \mathrm{~min}$. 


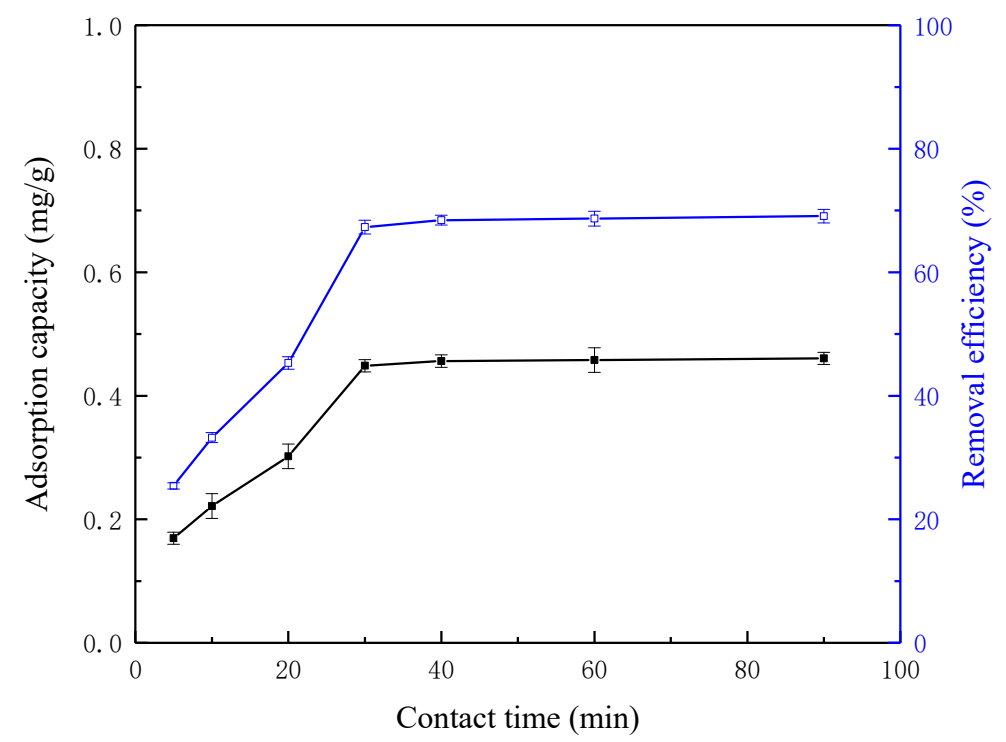

Figure 6. The effect of oscillation adsorption time on pyridine removal efficiency and adsorption capacity of pyridine.

\subsection{Effect of Initial Pyridine Concentration}

A $50 \mathrm{~mL}$ solution with different initial pyridine concentrations $(5,10,25,40$, and $80 \mathrm{mg} / \mathrm{L})$ was oscillated at $150 \mathrm{r} / \mathrm{min}$ for $30 \mathrm{~min}$ at $298 \mathrm{~K}$. Figure 7 shows the effect that the initial pyridine concentration has on the pyridine removal efficiency and adsorption capacity of pyridine by coke powder. The pyridine removal efficiency and adsorption capacity of pyridine generally increased as the initial pyridine concentration increased. When the initial concentration of pyridine was relatively low, the rate of increase in pyridine removal efficiency and adsorption capacity of pyridine was high with increasing the initial pyridine concentration. Interestingly, a slight increase was observed in the pyridine removal efficiency and adsorption capacity of pyridine as the initial pyridine concentration increased after $40 \mathrm{mg} / \mathrm{L}$. Adsorption power may account for this. This adsorption power mainly originates from the difference between the concentration of pyridine in the solution and that on the surface of coke powder during adsorption. When the initial pyridine concentration was low, a small effective collision probability was expected between the pyridine molecule and the effective adsorption point on the surface of coke powder, resulting in a low removal efficiency of pyridine. The larger the concentration difference, the higher the adsorption capacity and rate. With increasing the initial pyridine concentration, the effective collision probability increased, and thus the adsorption capacity and removal efficiency increased [22]. 


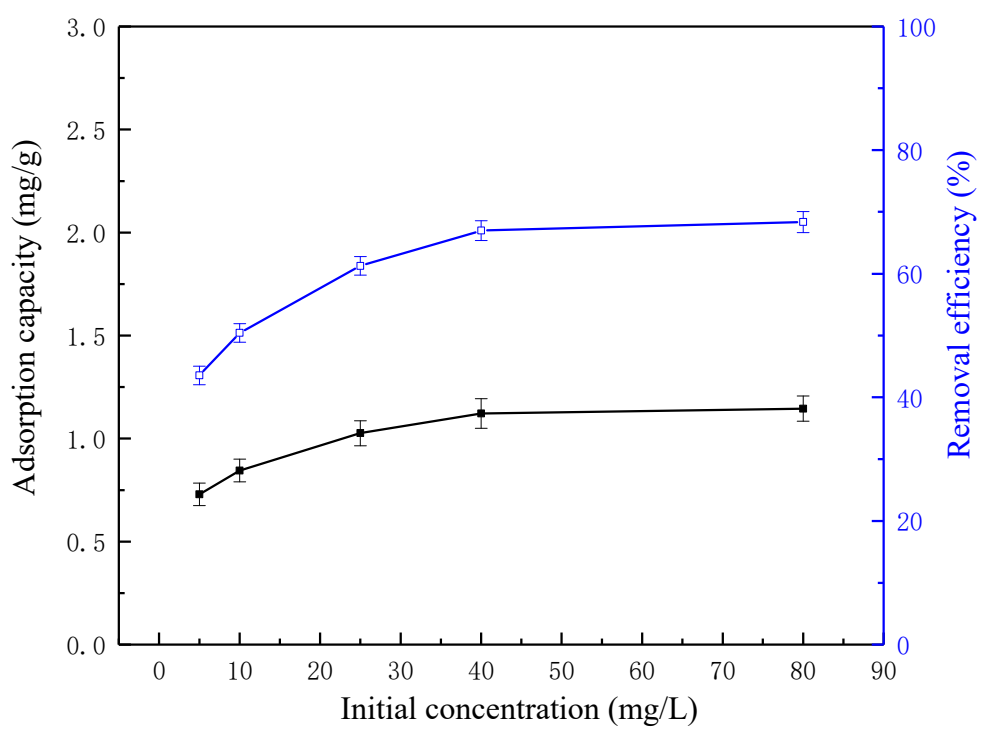

Figure 7. The effect of the initial concentration on pyridine removal efficiency and adsorption capacity of pyridine.

\subsection{Effect of Ash Content in Coke Powder}

Coke powder with different ash contents (27.37\% and $12.78 \%$ ) was used in the batch adsorption test. The pyridine concentration, coke powder concentration, oscillation speed, contact time, and temperature were $40 \mathrm{mg} / \mathrm{L}, 60 \mathrm{~g} / \mathrm{L}, 150 \mathrm{r} / \mathrm{min}, 30 \mathrm{~min}$, and $298 \mathrm{~K}$, respectively. Table 4 shows the removal efficiency of pyridine by coke powder with different ash contents. As can be seen, at different concentrations of coke powder in the solution, pyridine removal efficiency by coke powder with $27.37 \%$ of ash content was found always lower than that by coke powder with $12.78 \%$ of ash content. This indicates the significant effect of ash content on the pyridine removal efficiency using the coke powder. It is known that clay minerals are likely to slime coat the coke surface [32]. High ash content in the powder may reduce the pore numbers, which can significantly impact the adsorption behavior of coke powders, and therefore results in a low removal efficiency of pyridine.

Table 4. Removal efficiency of pyridine by coke powder with different ash contents.

\begin{tabular}{ccc}
\hline $\begin{array}{c}\text { Coke Powder Concentration } \\
(\mathrm{g} / \mathrm{L})\end{array}$ & $\begin{array}{c}\text { Pyridine Removal Efficiency by Coke } \\
\text { Powder with 27.37\% of Ash Content } \\
(\%)\end{array}$ & $\begin{array}{c}\text { Pyridine Removal Efficiency by Coke } \\
\text { Powder with 12.78\% of Ash Content } \\
\text { (\%) }\end{array}$ \\
\hline 5 & 27.23 & 28.50 \\
10 & 31.21 & 35.89 \\
20 & 35.89 & 47.65 \\
40 & 54.96 & 68.54 \\
60 & 66.97 & 85.20 \\
80 & 67.32 & 84.06 \\
\hline
\end{tabular}

\subsection{Effect of Solution $\mathrm{pH}$}

The effect of $\mathrm{pH}$ on the removal of pyridine in solution was investigated by performing batch adsorption tests at the solution $\mathrm{pH}$ ranging from 2 to 12 . The pyridine concentration, coke powder concentration, oscillation speed, contact time, and temperature were $40 \mathrm{mg} / \mathrm{L}, 60 \mathrm{~g} / \mathrm{L}, 150 \mathrm{r} / \mathrm{min}, 30 \mathrm{~min}$, and $298 \mathrm{~K}$, respectively. Figure 8 shows the effect of solution $\mathrm{pH}$ on the pyridine removal efficiency and adsorption capacity of pyridine by coke powder. Compared with the other investigated conditions mentioned above, this effect was found less evident. As can be seen, both the pyridine removal efficiency and adsorption capacity of pyridine decreased as the solution $\mathrm{pH}$ increased, suggesting the pyridine removal by coke powder be conducted in an acidic environment. Under acidic conditions, however, metal ions will be dissolved and released from coke powder, which is harmful to the environment. As 
little effect of solution $\mathrm{pH}$ was observed, and therefore the treatment of pyridine-containing solution is better conducted without $\mathrm{pH}$ regulations in a practical viewpoint.

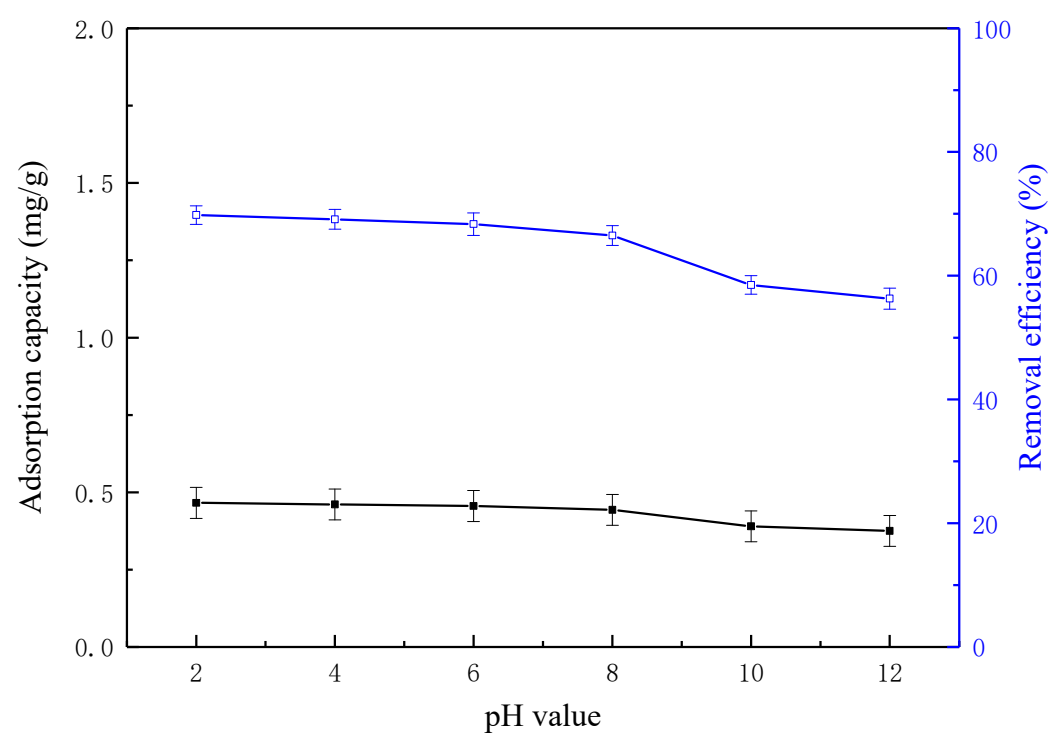

Figure 8. The effect of $\mathrm{pH}$ value on pyridine removal efficiency and adsorption capacity of pyridine.

\subsection{Reuse of Regenerated Coke Powder After Heat Treatment}

The regeneration of the coke powder was carried out in a resistance furnace with a heating temperature up to $573 \mathrm{~K}$ for $120 \mathrm{~min}$, and then the regenerated coke powder $(60 \mathrm{~g} / \mathrm{L})$ was reused to treat $50 \mathrm{~mL}$ solution with pyridine $(40 \mathrm{mg} / \mathrm{L})$ at an oscillation speed of $150 \mathrm{r} / \mathrm{min}$ for $30 \mathrm{~min}$ at $298 \mathrm{~K}$. Figure 9 shows the removal efficiency of pyridine as a function of reuse times of regenerated coke powder after heat treatment. With the increase in reuse times of regenerated coke powder, pyridine removal rate, and adsorption capacity of pyridine by coke powder decreased. The removal efficiency and the adsorption capacity of pyridine by coke powder was $66.97 \%$ and $0.44 \mathrm{mg} / \mathrm{g}$ using the raw coke powder without any heat treatment. After nine times of reuse, the removal efficiency and the adsorption capacity of pyridine by coke powder reduced to $52.56 \%$ and $0.35 \mathrm{mg} / \mathrm{g}$, respectively.

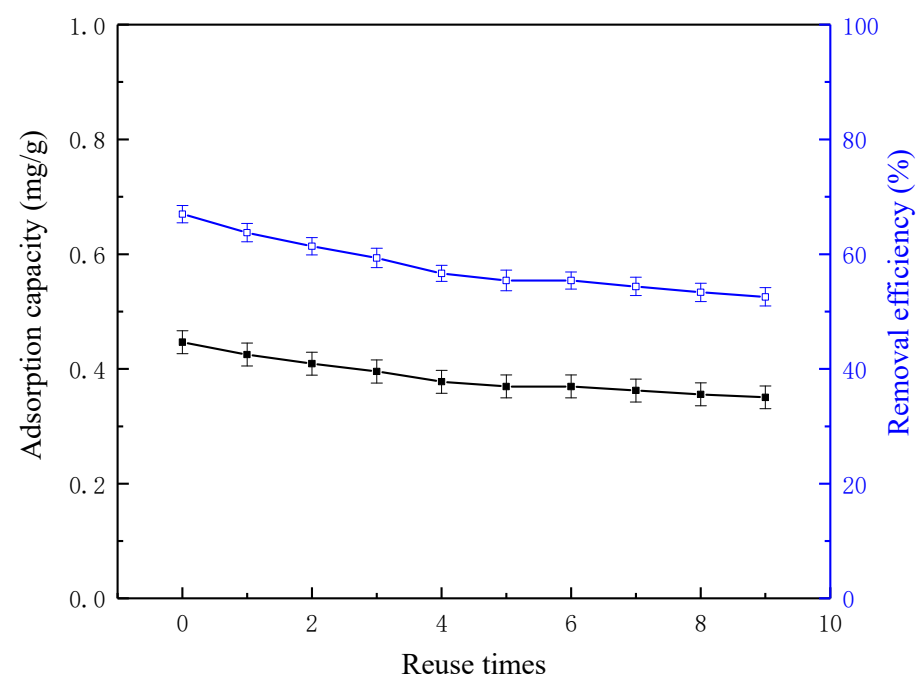

Figure 9. Relation between reuse times and pyridine removal efficiency and adsorption capacity of pyridine.

Since the boiling point of pyridine is $115.2^{\circ} \mathrm{C}$, the pyridine adsorbed by the coke powder can be digested by heat treatment. Figure 10 shows the surface of the reused coke powder. As can be seen, 
with the increase in the reuse times, the surface of coke powder became rougher, indicating that pore plugging and pore structure destruction occur in coke powder in the process of reuse, reducing the removal efficiency of pyridine.
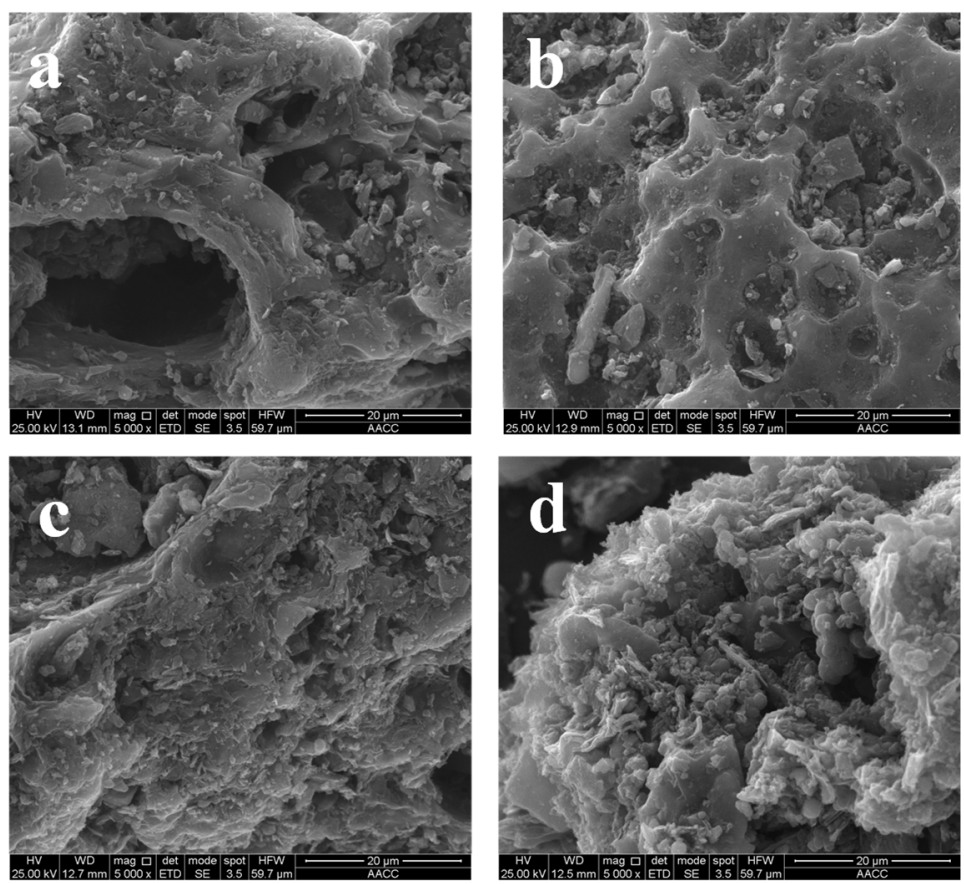

Figure 10. Surface morphology of reused coke powder. (a) Reused once, (b) reused three times, (c) reused five times, and (d) reused nine times.

The coke powder properties related to the pore before and after heat treatment were analyzed as shown in Table 5 and Figure 11. As can be seen, the pore size and mesoporous volume of coke powder increased after heat treatment, which is in favor of the adsorption of pyridine using the regenerated coke powder. However, this is somewhat counteracted by carbon deposition and pore plugging in the coke powder surface as a result of heat treatment reducing the specific surface area of the coke powder to decrease the pyridine removal efficiency. Thus, it explained a slight decrease in the removal efficiency and adsorption capacity of pyridine by the regenerated coke powder in the process of reuse.

Table 5. BET analysis of coke powder before and after heat treatment.

\begin{tabular}{cccccc}
\hline Adsorbent & $\begin{array}{c}\text { Number of } \\
\text { Reuses }\end{array}$ & $\begin{array}{c}\text { Specific Surface Area } \\
\left(\mathbf{m}^{\mathbf{2}} \mathbf{g}\right)\end{array}$ & $\begin{array}{c}\text { Average Pore } \\
\text { Size }(\mathbf{n m})\end{array}$ & $\begin{array}{c}\text { Mesoporous } \\
\text { Volume }\left(\mathbf{m}^{\mathbf{3}} \mathbf{g}\right)\end{array}$ & $\begin{array}{c}\text { Total Pore } \\
\text { Volume }\left(\mathbf{m}^{\mathbf{3}} / \mathbf{g}\right)\end{array}$ \\
\hline \multirow{4}{*}{ Coke } & 0 & 51.54 & 3.23 & 0.019 & 0.019 \\
powder & 1 & 51.34 & 7.43 & 0.021 & 0.025 \\
& 3 & 50.52 & 8.23 & 0.025 & 0.027 \\
& 5 & 50.23 & 9.56 & 0.031 & 0.036 \\
& 9 & 50.15 & 10.01 & 0.040 & 0.043 \\
\hline
\end{tabular}




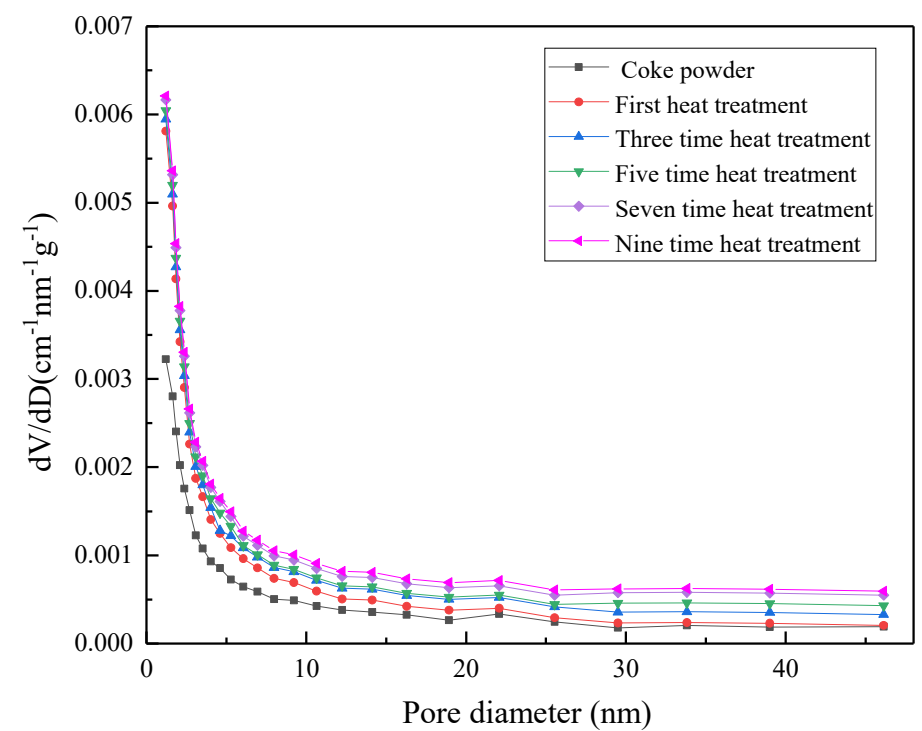

Figure 11. The change in the pore size distribution of coke powder before and after heat treatment.

Figure 12 shows the cumulative weight loss rate in coke powder after reuse. It increased with the increase in reuse times. Due to the good heat resistance and mechanical strength of the coke powder, the weight loss rate of coke powder was small in the reuse process. In addition, the curve was approximately linear, indicating that the weight loss rate of each reuse was nearly the same.

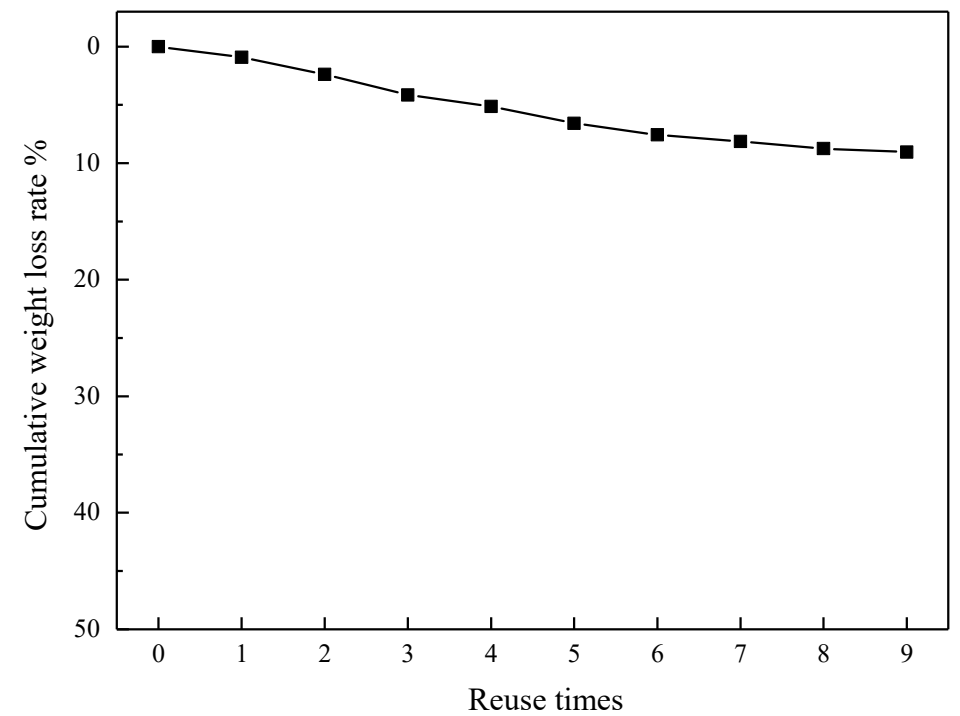

Figure 12. Relationship between coke powder adsorbent reuses times and the cumulative weight loss rate.

Figure 13 shows the FT-IR spectra of coke powder before and after heat treatment. The coke powder is mainly composed of $\mathrm{C}, \mathrm{H}, \mathrm{O}$, and $\mathrm{N}$, as shown by the characteristic peaks of $-\mathrm{OH},-\mathrm{C}=\mathrm{O}$, and $-\mathrm{C}-\mathrm{N}$ in Figure 13. After reuse, no new characteristic bands were produced, indicating the adsorption of pyridine using both the coke powder with or without heat treatment was mainly a physical adsorption process. 


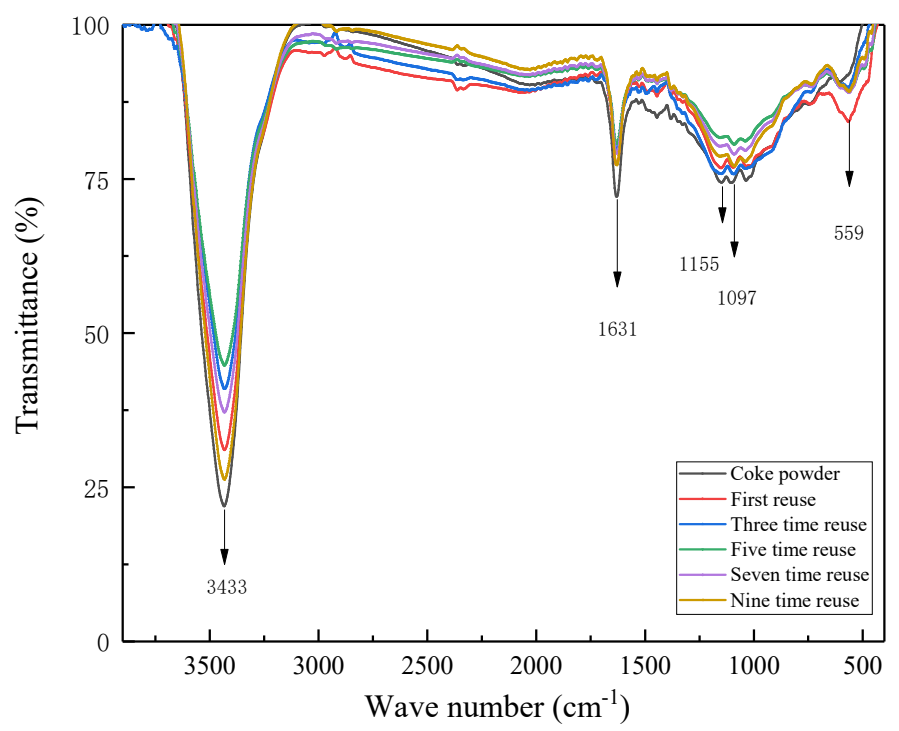

Figure 13. FT-IR results of coke powder adsorbent before and after heat treatment.

\subsection{Adsorption Isotherm Modeling}

Isothermal adsorption curve describes the relationship between the amount of adsorbate molecules adsorbed on the adsorbent surface and the concentration of adsorbate molecules in solution when the adsorption reaches equilibrium at constant temperature. The results of fitting the isotherm data using Langmuir, Freundlich, and Temkin isotherms are shown in Figures 14-16 and Table 6. The fitting shows that the adsorption of pyridine by coke powder can be well described by Freundlich isothermal adsorption model, and the correlation coefficient $\mathrm{R}^{2}$ was about 0.99 . This indicates that, apart from surface adsorption, pyridine was also adsorbed by coke powder in multi-molecular layers in the range of the examined pyridine concentrations. In addition, the fitted parameter $\mathrm{K}_{\mathrm{F}}$ and $1 / \mathrm{n}$ in the Freundlich isothermal adsorption model was found to be 0.9518 and 0.3531 , respectively, indicating that coke powder is capable of adsorbing pyridine readily. This provides insights into the adsorption behavior of pyridine onto coke powder and reasonable explanations for the high removal efficiency and excellent adsorption performance.

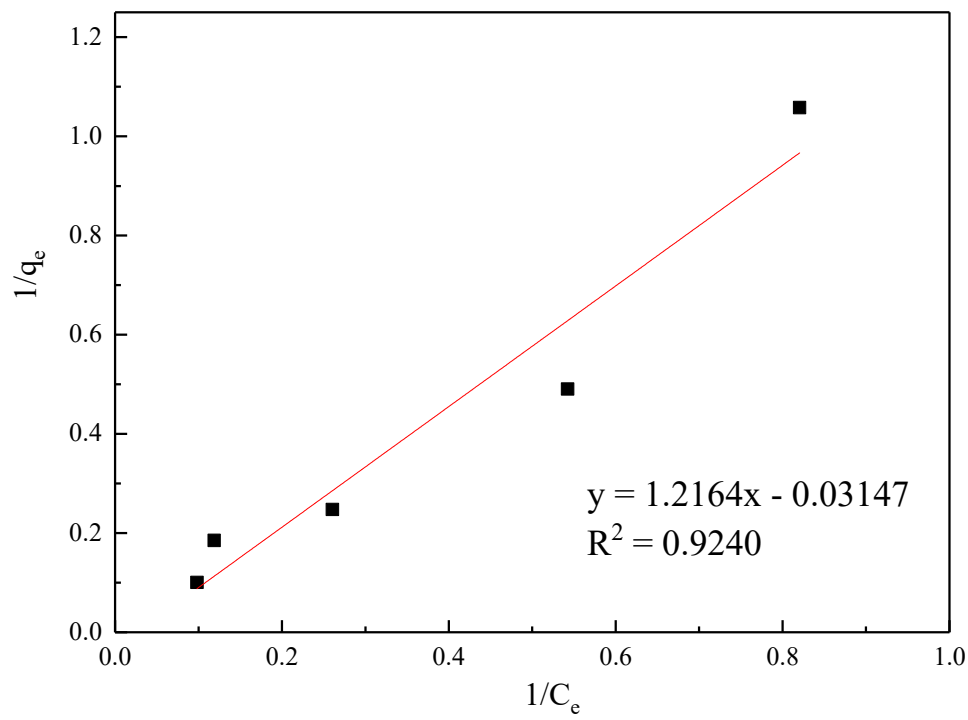

Figure 14. Linear regression of the Langmuir isotherm model (298 K). 


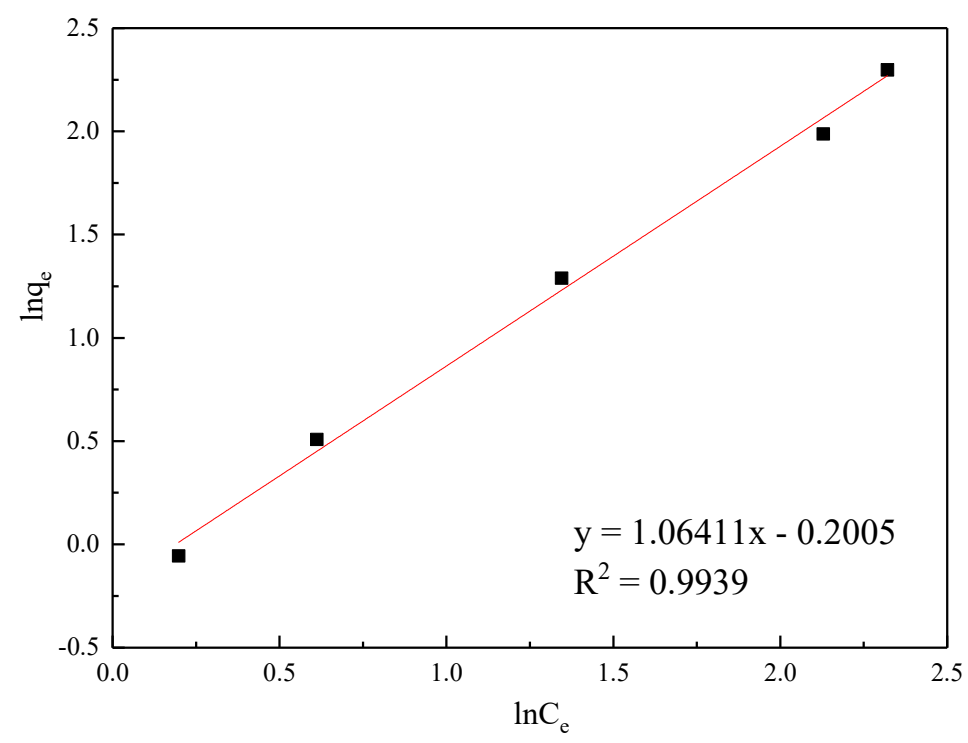

Figure 15. Linear regression of the Freundlich isotherm model (298 K).

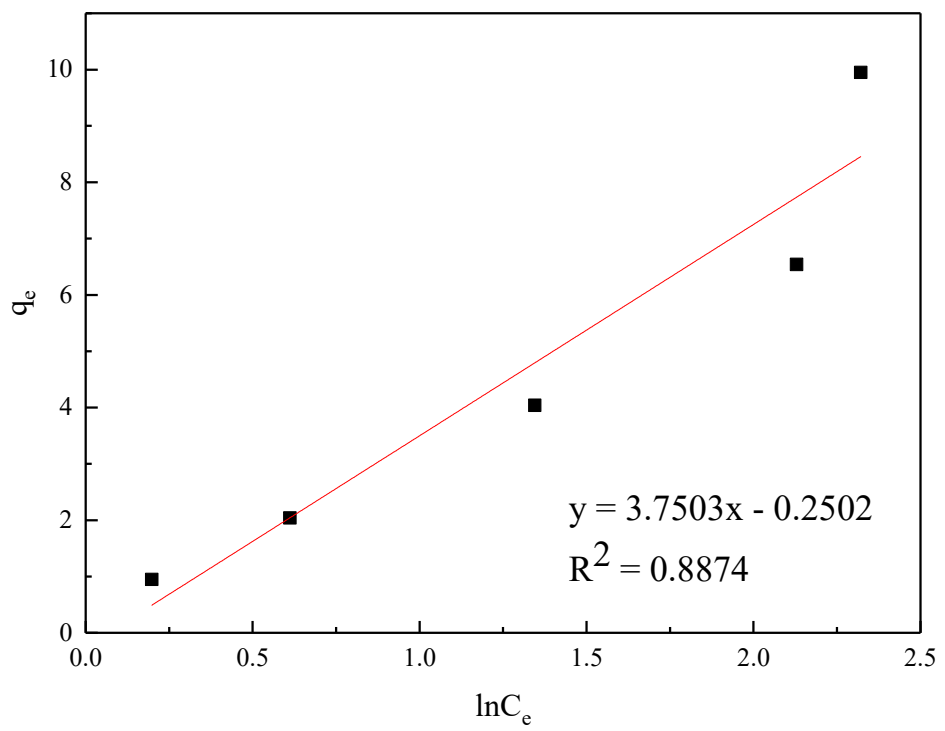

Figure 16. Linear regression of the Temkin isotherm model (298 K).

Table 6. Constants and correlation coefficients of the Langmuir, Freundlich, and Temkin isotherm models for pyridine adsorption on coke powder.

\begin{tabular}{|c|c|c|c|c|c|c|}
\hline Adsorbate & Adsorbent & $\begin{array}{l}\text { Isotherm } \\
\text { Models }\end{array}$ & Con & nts and Corr & n Coeffi & \\
\hline \multirow{3}{*}{ Pyridine } & \multirow{3}{*}{$\begin{array}{c}\text { Coke } \\
\text { powder }\end{array}$} & Langmuir & $\begin{array}{c}\mathrm{K}_{\mathrm{L}}(\mathrm{L} / \mathrm{mg}) \\
0.0529\end{array}$ & $\begin{array}{c}\mathrm{qm}_{\mathrm{m}}(\mathrm{mg} / \mathrm{g}) \\
31.7460\end{array}$ & $\begin{array}{c}\mathrm{R}_{\mathrm{L}}{ }^{\mathrm{a}} \\
0.8921\end{array}$ & $\begin{array}{c}\mathrm{R}^{2} \\
0.9240\end{array}$ \\
\hline & & Freundlich & $\begin{array}{c}\mathrm{K}_{\mathrm{F}}(\mathrm{L} / \mathrm{mg}) \\
0.9518\end{array}$ & $\begin{array}{c}1 / \mathrm{n} \\
0.3531\end{array}$ & - & $\begin{array}{c}\mathrm{R}^{2} \\
0.9939\end{array}$ \\
\hline & & Temkin & $\begin{array}{c}\mathrm{K}_{\mathrm{T}}(\mathrm{L} / \mathrm{mg}) \\
3.1571\end{array}$ & $\begin{array}{c}\mathrm{b}_{\mathrm{T}}(\mathrm{KJ} / \mathrm{mol}) \\
3.0592\end{array}$ & $\begin{array}{l}- \\
-\end{array}$ & $\begin{array}{c}R^{2} \\
0.8874\end{array}$ \\
\hline
\end{tabular}

\section{Conclusions}

The performance of coke powder adsorbing pyridine in a pyridine-containing wastewater was investigated, and the optimum operation conditions were determined. The optimum concentration of coke powder and adsorption time determined by the test were $60 \mathrm{mg} / \mathrm{L}$ and $30 \mathrm{~min}$, respectively. 
Pyridine removal efficiency and adsorption capacity of coke powder increased with increasing pyridine initial concentration. The coke powder with lower ash content exhibited a better adsorption performance. The $\mathrm{pH}$ of the solution was found to have little effect on the adsorption performance. Coke powder was regenerated by heat treatment, and after nine times of reuse, the removal efficiency, adsorption capacity of pyridine, and cumulative weight loss rate were found to be $52.56 \%, 0.35 \mathrm{mg} / \mathrm{g}$, and $9.04 \%$, respectively. Adsorption isotherm analysis showed that the adsorption of pyridine by coke powder could be well described by the Freundlich isothermal adsorption model, indicating the adsorption was physical, and the adsorption behavior was mainly multilayer adsorption on the surface.

Author Contributions: Conceptualization, Q.G., L.W., and Y.X.; Methodology, Q.G. and Z.L.; Writing-Original Draft Preparation, Q.G. and L.W.; Writing-Review and Editing, L.W., Q.X., and Q.H.; Resource, Y.W.

Funding: This research was funded by the Fundamental Research Funds for the Central Universities (No. 2018QNA29)

Acknowledgments: The funding provided by the Fundamental Research Funds for the Central Universities (No. 2018QNA29) which made this work possible is greatly acknowledged.

Conflicts of Interest: No potential conflict of interest was reported by the authors.

\section{References}

1. Zalat, O.A.; Elsayed, M.A. A study on microwave removal of pyridine from wastewater. J. Environ. Chem. Eng. 2013, 1, 137-143. [CrossRef]

2. Hong, Z.; Liang, L.; Hong, W.L. Fast photo-catalytic degradation of pyridine in nano aluminum oxide suspension systems. J. Environ. Sci. 2011, 23 (Suppl S), S156-S158.

3. Lee, S.T.; Lee, S.B.; Park, Y.H. Characterization of a pyridine-degrading branched gram-positive bacterium isolated from the anoxic zone of an oil shale column. Appl. Microbiol. Biotechnol. 1991, 35, 824-829. [CrossRef]

4. Mohan, S.V.; Sistla, S.; Guru, R.K.; Prasad, K.K.; Kumar, C.S.; Ramakrishna, S.V. Microbial degradation of pyridine using pseudomonas sp. and isolation of plasmid responsible for degradation. Waste Manag. 2003, 23, 167-171. [CrossRef]

5. Watson, G.K.; Cain, R.B. Microbial metabolism of the pyridine ring. metabolic pathways of pyridine biodegradation by soil bacteria. Biochem. J. 1975, 146, 157-172. [CrossRef] [PubMed]

6. Khasaeva, F.; Vasilyuk, N.; Terentyev, P.; Troshina, M.; Lebedev, A.T. A novel soil bacterial strain degrading pyridines. Environ. Chem. Lett. 2011, 9, 439-445. [CrossRef]

7. Kim, M.K.; Singleton, I.; Yin, C.R.; Quan, Z.X.; Lee, M.; Lee, S.T. Influence of phenol on the biodegradation of pyridine by freely suspended and immobilized pseudomonas putida mk1. Lett. Appl. Microbiol. 2010, 42, 495-500. [CrossRef] [PubMed]

8. Rhee, S.; Lee, S.; Lee, K.; Chung, J. Degradation of pyridine by nocardioides sp. strain os4 isolated from the oxic zone of a spent shale column. Can. J. Microbiol. 1997, 43, 205-209. [CrossRef]

9. Qiao, L.; Wang, J.L. Microbial degradation of pyridine by paracoccus sp. isolated from contaminated soil. J. Hazard. Mater. 2010, 176, 220-225. [CrossRef]

10. Yao, H.; Ren, Y.; Deng, X.; Wei, C. Dual substrates biodegradation kinetics of $\mathrm{m}$-cresol and pyridine by lysinibacillus cresolivorans. J. Hazard. Mater. 2011, 186, 1136-1140. [CrossRef]

11. Sun, J.Q.; Xu, L.; Tang, Y.Q. Degradation of pyridine by one Rhodococcus, strain in the presence of chromium (VI) or phenol. J. Hazard. Mater. 2011, 191, 62-68. [CrossRef] [PubMed]

12. Padoley, K.V.; Mudliar, S.N.; Banerjee, S.K. Fenton oxidation: A pretreatment option for improved biological treatment of pyridine and 3-cyanopyridine plant wastewater. Chem. Eng. J. 2011, 166, 1-9. [CrossRef]

13. Xu, Z.; Liu, Z.; Lu, X.; Xu, Y. Pretreatment process of organic wastewater containing pyridines. J. Environ. Eng. ASCE 2014, 8, 1863-1868.

14. Liu, S.; Wang, Q.; Sun, T.; Wu, C.; Shi, Y. The effect of different types of micro-bubbles on the performance of the coagulation flotation process for coke waste-water. J. Chem. Technol. Biotechnol. 2012, 87, 10. [CrossRef]

15. Lai, P.; Zhao, H.Z.; Wang, C.; Ni, J.R. Advanced treatment of coking wastewater by coagulation and zero-valent iron processes. J. Hazard. Mater. 2007, 147, 232-239. [CrossRef] [PubMed]

16. Yan-Bin, Z.; Ai-Wu, Z. Separation of pyridine and toluene by extractive distillation. Chem. Eng. 2012, 40, $13-16$. 
17. Lei, K.; Ming, L.I. Recovering pyridine from industrial waste water by means of continuous distillation. Pesticides 2005, 02, 69-71.

18. Zhu, Q.; Moggridge, G.D.; Ainte, M.; Mantle, M.D.; Gladden, L.F.; D’Agostino, C. Adsorption of pyridine from aqueous solutions by polymeric adsorbents $\mathrm{mn} 200$ and $\mathrm{mn}$ 500. Part 1: Adsorption performance and pfg-nmr studies. Chem. Eng. J. 2016, 306, 67-76. [CrossRef]

19. Larson, R.A.; Weber, E.J. Reaction Mechanisms in Environmental Organic Chemistry; CRC Press: Boca Raton, FL, USA, 1994; pp. 433-434.

20. Zhu, L.; Tian, S.; Shi, Y. Adsorption of volatile organic compounds onto porous clay heterostructures based on spent organobentonites. Clay Clay Min. 2005, 53, 123-136. [CrossRef]

21. Lataye, D.H.; Mishra, I.M.; Mall, I.D. Removal of pyridine from aqueous solution by adsorption on bagasse fly ash. Ind. Eng. Chem. Res. 2006, 45, 3934-3943. [CrossRef]

22. Gosu, V.; Gurjar, B.R.; Rao, Y.S.; Zhang, T.C. Treatment of pyridine-bearing wastewater by nano zero-valent iron supported on activated carbon derived from agricultural waste. Desalin. Water Treat. 2015, 57, 1-11. [CrossRef]

23. Ning, K.; Wang, J.; Xu, H.; Sun, X.; Huang, G.; Liu, G. Effects and mechanistic aspects of absorbing organic compounds by coking coal. Water Sci. Technol. 2017, 76, 2280-2290. [CrossRef]

24. Gao, L.; Li, S.; Wang, Y. Effect of different ph coking wastewater on adsorption of coking coal. Water Sci. Technol. 2016, 73, 582-587. [CrossRef]

25. He-Ming, L.; Shu-Rong, Y.U.; Hui-Xia, F.; Jian-Qiang, Z.; Xia, Z.; Yi, W. The mechanism and properties of methylene blue adsorption on modified coke powder. J. China Coal Soc. 2009, 34, 971-976.

26. Peng, D.; Xiao-Rui, W. Research on adsorption performance of fluorin ion over modified coke. Contemp. Chem. Ind. 2014, 43, 1163-1165.

27. Mall, I.D.; Srivastava, V.C.; Agarwal, N.K.; Mishra, I.M. Adsorptive removal of malachite green dye from aqueous solution by bagasse fly ash and activated carbon-kinetic study and equilibrium isotherm analyses. Coll. Surface A 2005, 264, 17-28. [CrossRef]

28. Basar, C.A. Applicability of the various adsorption models of three dyes adsorption onto activated carbon prepared waste apricot. J. Hazard. Mater. 2006, 135, 232-241. [CrossRef]

29. Mori, A.; Maksimov, I.L. On the temkin model of solid-liquid interface. J. Cryst. Growth 1999, 200, $297-304$. [CrossRef]

30. Zhang, M.; Wang, Y.; Liu, J. Utilization of mineral processing flocculants in dewatering of coal slimes. China Coal 2003, 29, 46-47.

31. Zhou, X.; Ma, L.; Yang, J.; Huang, B.; Zou, Y.; Tang, J. Properties of graphitized boron-doped coal-based coke powders as anode for lithium-ion batteries. J. Electroanal. Chem. 2013, 698, 39-44. [CrossRef]

32. Pandey, H.D.; Prasad, M.S. Effect of moisture on the accuracy of coke-ash determination by x-ray backscattering. Spectrochim. Acta Part B Atom. Spectr. 1984, 39, 943-946. [CrossRef] 